\title{
Teoretický model pro formativní hodnocení při badatelsky orientované výuce matematiky a prírodopisu ${ }^{1}$
}

\section{Libuše Samková, Lukáš Rokos, Jan Petr, Iva Stuchlíková}

\begin{abstract}
Abstrakt: Předkládaná teoretická studie se zaměruje na otázky souvisejici s propojenim formativniho hodnoceni a badatelsky orientované výuky ve školni praxi a $k$ této problematice pristupuje společně pro matematiku a prírodovědné prédmèty (konkrétnè prírodopis). Na základè společných rysů badatelsky orientované výuky v obou predmètech a s využitím teoretického modelu pro popis interakci při poskytováni okamžité zpětné vazby učitelem jsme vytvorili nový teoretický model pro popis interakci pri formativnim hodnoceni realizovaném bèhem badatelsky orientované výuky. Výsledný teoretický model pro formativni hodnoceni pri badatelsky orientované výuce prédstavujeme prostrednictvím sady schémat, která obecnè popisuji prübèh výukového bloku s badatelskou úlohou z pohledu formativního hodnoceni, a prostrednictvím nového tzv. double:ESRU modelu pro kódováni rüzných typů interakci, ke kterým docházi pri formativnim hodnoceni. Možnosti teoretického modelu ilustruji podrobné analýzy dvou virtuálních výukových blokü s badatelskou úlohou (matematického a prírodopisného). Prezentovaný model nabizi pedagogickému výzkumu nástroj pro podrobnou priléhavou analýzu formativního hodnoceni pri badatelsky orientované výuce, učitelìm a budoucim učitelìm nabizi nástroj pro podporu implementace formativního hodnoceni a badatelského prístupu do jejich vlastni výuky. Vizualizace propojeni obou př́stupĩ a nezávislost modelu na školnim predmètu by mély pomoci porozumèt možnostem, které formativni hodnoceni pri badatelsky orientované výuce nabizi.
\end{abstract}

Klíčová slova: badatelsky orientovaná výuka, formativni hodnoceni, interakce, matematické vzděláváni, prírodopisné vzdèlávání

\section{ÚvOD}

Badatelsky orientovaná výuka (BOV) a formativní hodnocení (FH) jsou dva vybrané prístupy, které jsou v posledních dese- tiletích diskutovány v souvislosti s možnými proměnami současného vzdělávání. BOV proto, že již od roku 2007 je i na evropské úrovni považována za jednu z cest zkvalitňování a vyšší atraktivity prírodovědného

\footnotetext{
${ }^{1}$ Realizováno s podporou TA ČR, projekt Hyperspace pro formativní hodnocení a badatelsky orientovanou výuku $v$ prírodovèdných predmètech a matematice (TL02000368).
} 
vzdělávání (Rocard et al., 2007), a FH proto, že výsledky a vývoj učení žáka během BOV jsou v principu poměrně obtížně hodnotitelné a právě tento hodnoticí př́istup je nástrojem, který může v této situaci pomoci (Dolin \& Evans, 2018). Jak je vidět, oba dva prístupy spolu těsně souvisejí a ukazuje se, že jejich vzájemné propojení je potřebné a užitečné. Nejen to, oba mají také některé společné rysy, které dále opodstatňují jejich vzájemné propojení. Jak při BOV, tak při FH mají žáci více autonomie, jsou spoluzodpovědní za svůj úspěch v procesu učení. Oba př́stupy vychází shodně ze sociálně konstruktivistické teorie vyučování. Jsou založeny na hloubkovém učení, které vede $\mathrm{k}$ vytváření detailnějších a přenositelnějších znalostních schémat a modelů (Bransford, Brown \& Cocking, 2000). Jestliže se mají žáci učit hloubkovým způsobem, tedy má-li být činnost a motivace žáků funkčně integrována s obsahem a cíli výuky, je nutné jim dát $\mathrm{k}$ tomu prostor a nechat je přijmout aktivní roli v procesu učení, ale i umožnit jim zapojit se do diskuse o obsahu učiva (Janík et al., 2013). Vzájemné propojení $\mathrm{BOV}$ a FH takové učební prostředí nabízí.

Pedagogickou veřejností bývá BOV často vnímána jen ve vztahu k př́rodovědnému vzdělávání, přestože je možné ji realizovat i v jiných školních předmětech, např́klad $\mathrm{v}$ matematice (Artigue \& Blomhøj, 2013). Převažující vazba na prrírodovědné předměty je pravděpodobně důsledkem toho, že první evropské kurikulární dokumenty zahrnující bádání se týkaly prrírodovědného vzdělávání (Rocard et al., 2007), a také toho, že v USA, kde se takové dokumenty objevily o desetiletí dříve než v Evropě (NRC, 1996), je bádání dodnes vztahováno hlavně $\mathrm{k}$ přírodovědným předmětům (Schoenfeld \& Kilpatrick, 2013). $\mathrm{V}$ našem prŕspěvku bychom rádi představili prŕstup, který jde nad rámec přírodovědného vzdělávání a který na $\mathrm{BOV}$ nahlíží $\mathrm{v}$ různých školních předmětech stejně.

Příspěvek je teoretickou studií odvozující a představující komunikační model propojení BOV a FH. Předkládaný model je univerzální $\mathrm{v}$ tom smyslu, že vychází z rysů $\mathrm{BOV}$ a $\mathrm{FH}$, které jsou společné pro výuku matematiky a výuku př́rodopisu, a tak se může stát základem pro prŕpravu, realizaci a analýzu výuky obou těchto předmětů. $\mathrm{Na}$ model pohlížíme z perspektivy ideálně zrealizované výuky a ilustrujeme ho prostřednictvím hypotetických ukázek dvou výukových bloků s badatelskou úlohou - matematického a př́rodopisného.

Předkládaná studie je výchozí úvahou první etapy výzkumného projektu podporovaného TA ČR Hyperspace pro formativni hodnoceni a badatelsky orientovanou výuku v prírodovédných predmètech a matematice, který je řešen ve spolupráci Jihočeské univerzity v Českých Budějovicích a Masarykovy univerzity v Brně. Cílem uvedeného projektu je vytvořit virtuální vzdělávací a podpůrné prostředí (hyperspace) pro učitele a studenty učitelství, reagující na potřebu podpory př́i zavádění $\mathrm{BOV}$ a $\mathrm{v}$ ní užívaného $\mathrm{FH}$ do jejich pedagogické praxe. Navržený teoretický model se má stát východiskem architektury hyperspace. 


\section{TEORETICKÁ VÝCHODISKA}

\section{Badatelsky orientovaná výuka}

Badatelsky orientovaná výuka (BOV) terminologicky vychází $\mathrm{z}$ anglického pojmu „inquiry“ (bádání, objevování, zkoumání apod.). Rozpracování bádání jako pedagogického prŕstupu je připisováno Johnu Deweymu (1938). Dewey se odvolává na předchozí pedagogické koncepce Humboldta, Pestalozziho, Frobela a Herbarta, které v procesu poznávání zdůrazňovaly přemýšlení, reflexi a experimentování (Artigue \& Blomhøj, 2013). Základní idea spočívá $\mathrm{v}$ tom, že proces učení je charakterizován spoluprací učitele a žáků $s$ tím, že dává prostor pro aktivitu žáků samotných a pro jejich objevování (bádání) při osvojování si nových znalostí a dovedností. BOV souvisí v teoretické rovině s konstruktivismem (Cakir, 2008), zejména $s$ konstruktivismem sociálním (Mayer, 2004). Zjednodušeně lze říci, že učení při BOV není chápáno jako pasivní přijímání znalostí, ale jako přirozená, stále se opakující aktivita, při které je obraz světa, který poznávající má, doplňován a upravován.

BOV bývá často obecně vymezována jako výuka, př̀ které je žákům nabídnuta možnost používat postupy a metody práce analogické těm, které při své výzkumné práci používají odborní vědečtí pracovníci (Dorier \& Maaß, 2014). V zahraniční odborné literatuře nalezneme nespočet označení pro výuku, v níž žák od učitele dostává namísto hotových vědomostí préedevším podporu $\mathrm{v}$ procesu učení (Kirschner, Sweller \& Clark, 2006). Př́kladem může být učení objevováním (Bruner, 1961), učení řešením problémů (Barrows \& Tamblyn, 1980; Pólya, 2016), konstruktivistické učení (Steffe \& Gale, 1995), zkušenostní učení (Kolb \& Fry, 1975), a také badatelsky orientované vyučování (Rutherford, 1964). Ačkoli jsou jednotlivé př́stupy různě označovány, z pedagogického hlediska mají stejnou podstatu (Kirschner, Sweller \& Clark, 2006).

Jak již bylo zmíněno $\mathrm{v}$ úvodu, BOV bývá často vnímána jen ve vztahu k přírodovědnému vzdělávání, nicméně tento př́stup $\mathrm{k}$ výuce je možné realizovat i v jiných školních předmětech, např́íklad v matematice. Př́i vhodném uchopení je možné prezentovat jednotlivé aspekty a souvislosti $\mathrm{BOV} \mathrm{v}$ různých předmětech společně, podobně jako $\mathrm{v}$ př́padě schématu na obrázku 1: schéma sice představuje hlavní aspekty BOV z pohledu př́rodovědných předmětů, ale je plně platné i v matematice - stačí jen v rámečku uprostřed nahradit termín prírodovědná gramotnost termínem matematická gramotnost.

$\mathrm{V}$ českém vzdělávacím prostředí se podobně jako ve světě věnovala pozornost BOV nejprve u prrírodovědných předmětů. Můžeme se setkat $s$ teoretickými studiemi, které vymezují pojem bádání a jeho jednotlivé úrovně nebo se věnují možnostem a limitům tohoto prístupu (Papáček, 2010), ale i s empirickými studiemi, které sledují úlohy, žáky i učitele: efektivitu badatelských úloh ve vztahu $\mathrm{k}$ osvojení si nových znalostí (např. Činčera, 2013; 


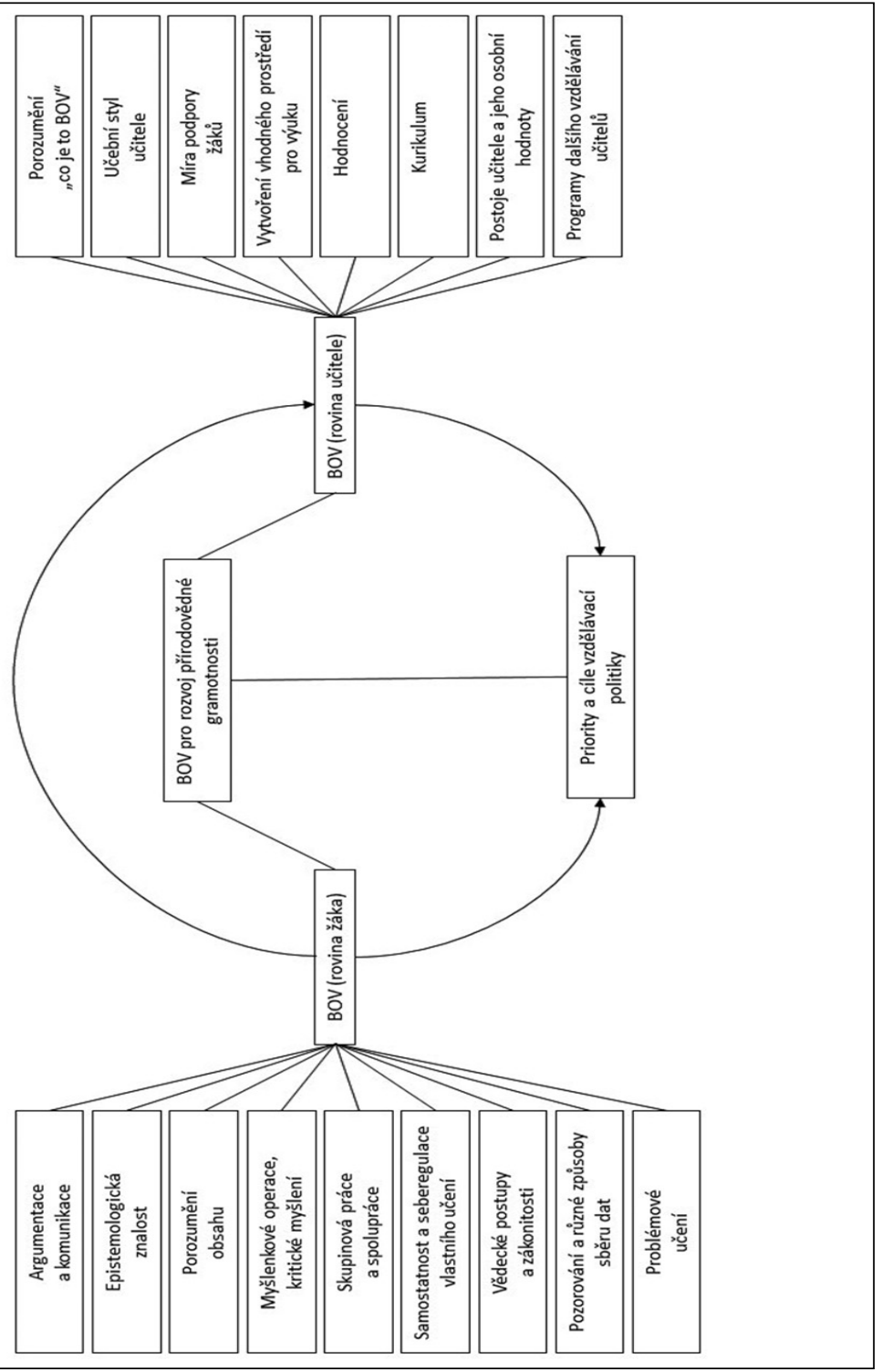

Obr. 1. Hlavní aspekty BOV v přírodovědných předmětech (Tsivitanidou et al., 2018, s. 8, vlastní překlad) 
Rokos \& Vomáčková, 2017; Vácha \& Ditrich, 2016), souvislost mezi bádáním a motivací žáků (Škoda et al., 2015), učitele a jejich postoje $\mathrm{k}$ tomuto př́stupu (Radvanová, Čížková \& Martinková, 2018). V oblasti výuky matematiky byla publikována teoretická studie zkoumající vymezení BOV v matematice a jeho vztah $\mathrm{k}$ vymezení $\mathrm{BOV} \mathrm{v}$ př́rodovědných předmětech, vztah BOV $\mathrm{k}$ různým didaktickým rámcům matematického vzdělávání a typologii matematických badatelských úloh (Samková et al., 2015). Empirické studie se věnují postojům učitelů $\mathrm{k}$ BOV (např. Novák \& Nováková, 2014; Nocar, Polejová \& Laitochová, 2017), možnostem využití $\mathrm{BOV} \mathrm{v}$ přípravě budoucích učitelů (např. Samková, Hošpesová \& Tichá, 2016; Samková, 2018), možnostem a limitům BOV ve školní praxi (Hošpesová, 2016).

\section{Formativní hodnocení}

Podobně jako u BOV, ani u FH není hlavní myšlenka tohoto konceptu nijak nová, o tomto hodnoticím prŕstupu se již zmiňuje např́iklad Scriven (1967). Důležitým mezníkem v nazírání na $\mathrm{FH}$ se stala rozsáhlá publikace Blacka a Wiliama (1998), jejíž autoři mj. došli k závěru, že použití FH má pozitivní vliv na dosažené výsledky učení. Vymezení $\mathrm{FH}$ se podle různých autorů liší. Jednu z komplexních definic přináší Heritageová (2007, s. 141), která definuje FH jako „systematický proces soustavného shromaždování informací o tom, jak probíhá žákovo učení. Tyto informace jsou následně využívány $\mathrm{k}$ iden- tifikaci aktuální úrovně výsledků učení a umožňují upravit další kroky výuky tak, aby bylo dosaženo cílů učení.“ Žáci jsou při procesu hodnocení aktivními aktéry, sdílejí cíle učení s učitelem, chápou, jak se proces jejich učení odvíjí a jaké další kroky je nezbytné uskutečnit, aby byl tento proces efektivnější (Heritage, 2007).

Grafika na obrázku 2 ilustruje vzájemné vztahy jednotlivých aktivit $\mathrm{FH}$ se zřetelem $\mathrm{k}$ předem definovaným vzdělávacím cílům dané hodiny, popřípadě delšího úseku výuky. Žáci stojí v centru celého procesu a šipky, které ve schématu směřují od žáků $\mathrm{k}$ jednotlivým krokům cyklu a zpět, symbolizují, že žáci nejen obdrží zpětnou vazbu od učitele, ale zároveň jsou zdrojem informací o úspěšnosti procesu učení pro učitele. Pokud je to vhodné, tak se žáci aktivně zapojují i do rozhodování o dalších krocích v cyklu. Šipky ve schématu nepředstavují konkrétní fáze vyučovací hodiny, které by si učitel předem detailně naplánoval. Jejich umístění v rámci hodiny závisí na informacích, které učitel od žáků během hodiny průběžně získává. $\mathrm{Na}$ základě těchto informací si učitel může jednotlivé kroky upravit tak, aby žáci snáze dosáhli vytyčených vzdělávacích cílů. Ze schématu je patrné, že klíčovým prvkem FH je zpětná vazba. Je však důležité zdůraznit, že zpětná vazba sama o sobě není $\mathrm{FH}$, za které je často mylně zaměňována. Cílem zpětné vazby jako základu FH je umožnit překonání rozdílu mezi dosavadní úrovní žákových znalostí či dovedností a úrovní, kterou si učitel stanovil jako žádoucí cílový stav (Hattie \& Timperley, 2007). Zpětná vazba posky- 
tuje učiteli informace, které mu napomáhají usměrnit další výuku. Žák získává informace o tom, jak jeho dosavadní učení probíhá (Nicol \& Mcfarlane-Dick, 2006). $\mathrm{Na}$ efektivitu zpětné vazby má vliv řada faktorů, např́iklad učební styl žáka, osoba učitele, klima v dané třídě, užité vyučovací metody a formy, ale i jazyková úroveň žáka a jeho dosavadní znalosti a dovednosti (Evans et al., 2016). Aby učitel mohl ve výuce $\mathrm{FH}$ efektivně využívat, musí mít jasnou představu o tom, proč toto hodnocení použivá a jaký je jeho hlavní smysl. Jednání učitele v dané situaci závisí nejen na jeho pedagogických a oborových zna- lostech (Magnusson, Krajcik \& Borko, 1999), ale rovněž na konkrétní situaci, která během výuky nastala (Cross \& Lepareur, 2015).

Mezi českými odbornými publikacemi o FH nalezneme monografii věnující se klíčovým krokům pro efektivní zařazení $\mathrm{FH}$ do výuky (Starý \& Laufková et al., 2016), překlad praktického průvodce FH pro učitele základních a středních škol (Wiliam \& Leahy, 2016), teoretické studie, které vymezují $\mathrm{FH}$ a věnují se potenciálním možnostem jeho využití ve výuce (Shánilová, 2010), a také empirické studie zaměřené na různé způsoby začle-

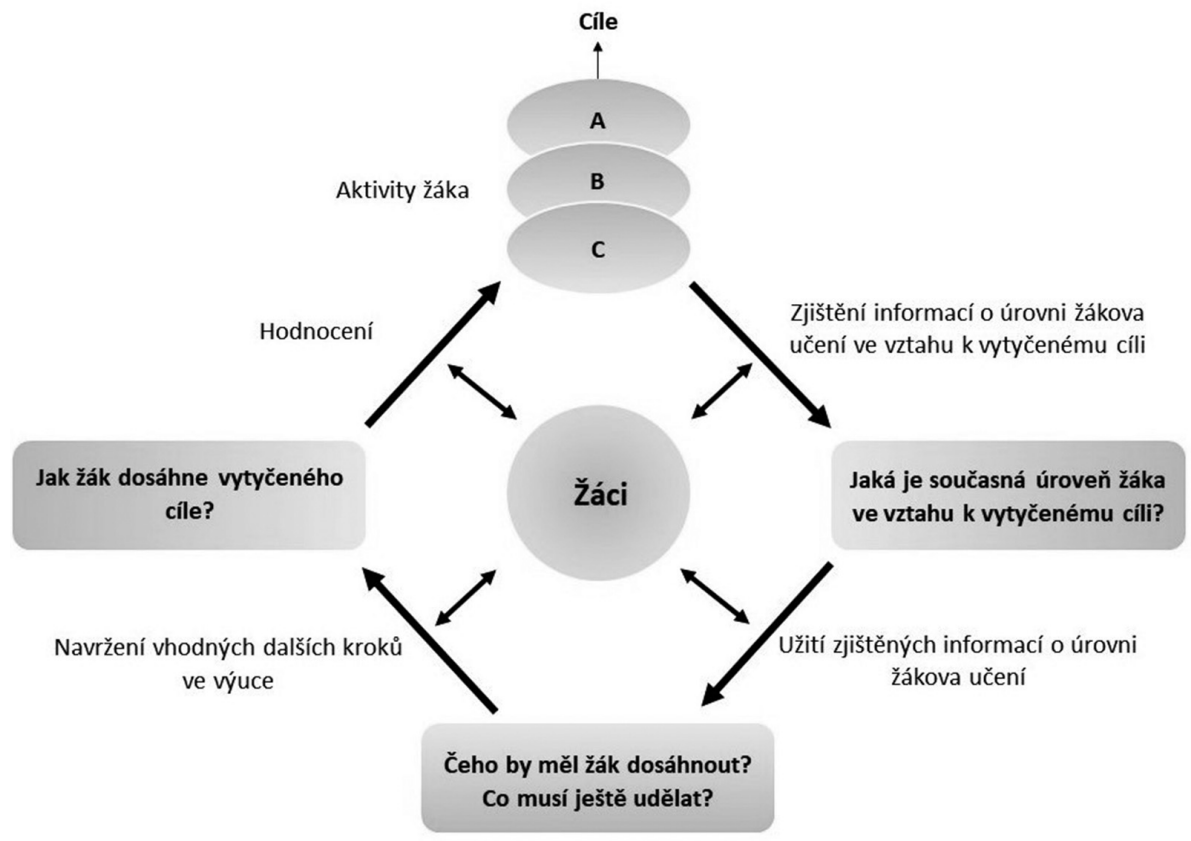

Obr. 2. Schéma formálního hodnocení (Harlen, 2013, s. 120, vlastní překlad) 
ňování $\mathrm{FH}$ do výuky (Novotná \& Krabsová, 2013; Laufková, 2017; Hošpesová, 2018), na kvalitu zpětné vazby poskytované učitelem nebo spolužáky (Kosíková \& Černá, 2013; Rokos \& Lišková, 2019) či na postoje žáků k FH (Rokos a kol., 2016). Některé z těchto publikací se věnují FH v kontextu BOV (Hošpesová, 2018; Rokos et al., 2016) a poukazují na úzkou souvislost FH a BOV.

Při výuce je možné používat různé metody FH (jejich soupis uvádějí např́íklad Wiliam \& Leahy, 2016), při sestavování našeho modelu jsme využívali kombinaci následujících tří metod.

\section{Poskytování okamžité zpětné vazby („on-the-fly“ hodnocení)}

Interakce učitele se žáky „on-the-fly“ můžeme do češtiny volně přeložit jako „poskytování okamžité zpětné vazby“. Shavelson et al. (2008) nebo Christie (2002) charakterizují tyto interakce jako neplánované $\mathrm{FH}$, protože učitel při nich využívá vhodné momenty ve výuce, které mohou posloužit $\mathrm{k}$ rozpoznání mylných představ žáků, $\mathrm{k}$ nasměrování žáků ke správnému porozumění nebo $\mathrm{k}$ vysvětlení nejasné látky (Heritage, 2007).

Ruizová-Primová a Furtaková (2006) nabízejí teoretický model, prostřednictvím kterého je možné okamžitou zpětnou vazbu analyzovat, tzv. model ESRU. Akronym tohoto modelu je odvozen od počátečních písmen charakterizujících čtyři na sebe navazující kroky při poskytování okamžité zpětné vazby:

První krokem je vyvoláni interakce („E“ $\mathrm{z}$ angl. eliciting), kdy učitel žáka žádá o jednoznačné určení významu daného pojmu, interpretaci pojmů nebo jevů na obrázku či schématu, srovnání a seřazení jednotlivých pojmů nebo jevů, uvedení př́íkladů nebo důkazů, navržení postupu při řešení daného problému či úlohy. Za tímto účelem učitel pokládá otázky ke kontrole porozumění žáka, např́klad „Jak? Jakým způsobem...?, Jaké jsou...? Co znamená...? Kdo si pamatuje něco o...? Jak dělíme...?“. Místo položení otázky může učitel také předložit svůj vlastní názor nebo vznést námitku.

Druhým krokem je reakce žáka („S“ $\mathrm{z}$ angl. student's response), kdy žák reaguje na otázku, názor nebo námitku učitele z předchozího kroku.

Třetím krokem je rozpoznáni reakce čili odezva učitele na reakci žáka a identifikace jejího obsahu („R“ z angl. recogni$z i n g$ ). Učitel $\mathrm{v}$ tomto př́ípadě zaregistruje, zopakuje nebo přeformuluje odpověd' žáka. Dále tuto odpověd' může vyjasnit či požadovat od žáka její doplnění. Zároveň může poskytnout zřetelnou zpětnou vazbu (hodnoticí výroky, ale také odpovědi typu „ano/ne“), popřípadě požádat žáka, aby zopakoval jinými slovy to, co řekl jeho spolužák.

Čtvrtý a pro učitele patrně i nejobtížnější krok je užití zjištěných informací („U“ $\mathrm{z}$ angl. using). Zde se učitel snaží podpořit další přemýšlení žáků tak, aby sami došli ke správnému závěru. Pomáhá jim spojit zjištěné informace $s$ předchozím učivem, porovnává jejich různé myšlenky či pohledy na danou problematiku, popř́padě jim poskytuje určitou oporu pro snazší dosažení vytyčeného vzdělávacího cíle. 


\section{Vrstevnické hodnocení}

Další podobou FH je vrstevnické hodnocení, tedy zpětná vazba, kterou žáci poskytují navzájem jeden druhému, přičemž učitel funguje jen jako pozorovatel nebo rádce, pokud ho o to žáci požádají. Realizace vrstevnického hodnocení je založena na předpokladu, že žáci jsou při výuce aktivní, radí svým spolužákům (Leahy et al., 2005) a jsou schopni akceptovat kritiku své práce od jiného žáka. Vrstevnické hodnocení je užitečné i proto, že vzájemná výměna nápadů a rad probíhá v řeči žáků, tj. je formulována slovními obraty, které žáci běžně užívají (Black et al., 2004; Mathan \& Koedinger, 2005). Interakce mezi žáky a jejich projekce do poskytované zpětné vazby jsou klíčovým prvkem (Raes, Vanderhoven \& Schellens, 2015) a žáci se od sebe mohou učit i přesto, že jejich intelektuální úroveň může být odlišná (Starý \& Laufková et al., 2016). Ze začátku je bezpochyby vhodné žákům vytvořit určitou podporu, která je nasměruje na klíčové prvky hodnocení (Panadero, Romero \& Strijbos, 2013), a nechávat je hodnotit úkoly, jež odpovídají jejich úrovni znalostí vztahujících se $\mathrm{k}$ dané problematice (Mathan \& Koedinger, 2005).

\section{Otevřená nebo strukturovaná diskuse se žáky ve tř́ídě}

Podnětem k otevřené nebo strukturované diskusi se žáky ve tř́ídě obvykle bývá otázka nebo téma. Učitel žáky požádá, aby vyjádřili své myšlenky nebo názory na daný problém. Zjištuje tím, jak žáci problému či tématu porozuměli. Někteří autoři v tomto smyslu hovoří o „dobrých otázkách“ a konstatují, že není pro učitele jednoduché tyto otázky formulovat (Jančaříková \& Novotná, 2019). Alternativou k „dobré otázce“ jako podnětu $\mathrm{k}$ diskusi se žáky může být také výzva učitele $\mathrm{k}$ posouzení pravdivosti odpovědi (přednesené učitelem nebo některým z žáků), prúípadně požadavek na výběr správné odpovědi $\mathrm{z}$ několika různých možností. Black et al. (2004) zdůrazňují, že při takové diskusi je velmi důležité nechat žákům dostatek času na přemýšlení, př́ípadně prostor pro diskusi ve dvojících nebo malých skupinkách. Učitel by pak měl podpořit diskusi a reflexi žáků otázkami jako „Proč...? Jaký je rozdíl mezi experimenty? Co je shodné a co je rozdílné...?" (Black et al., 2004). Z pohledu kognitivní náročnosti je možné v diskusi rozlišovat čtyři typy otázek (Šed’ová, Švaříček \& Šalamounová, 2012): uzavřené otázky nižší kognitivní náročnosti (zaměřené na sdělení dříve osvojeného faktu nebo doslovné vybavení si faktu, který byl v minulosti prezentován učitelem), uzavřené otázky vyšší kognitivní náročnosti (vyžadující aplikaci nějakého pravidla), otevřené otázky nižší kognitivní náročnosti (např́klad dotazování na velmi početnou množinu objektů, které žáci postupně vyjmenovávají), nebo otevřené otázky vyšší kognitivní náročnosti (směřující $\mathrm{k}$ analýze, hodnocení či tvořivému výkonu). Stejné čtyřri typy se uplatňují i u odpovědí. 


\section{TeOReTICKÝ MOdel FH PŘI BOV}

\section{Tvorba modelu}

Při tvorbě teoretického modelu $\mathrm{FH}$ při BOV jsme vycházeli z modelu badatelského cyklu (Anderson, 2002) a z modelu ESRU pro hodnocení on-the-fly (Ruiz-Primo \& Furtak, 2006). Vzhledem k uvažovanému využití modelu jako výchozího schématu pro virtuální prostředí hyperspace jsme však model badatelského cyklu rozložili na jednotlivé kroky a hledali jeho co nejjednodušší univerzální podobu, která by byla aplikovatelná na libovolnou badatelskou úlohu bez ohledu na vyučovací předmět. Vzhledem $\mathrm{k}$ uvažovanému využití modelu jako metodické pomůcky pro učitele při jejich snaze o implementaci BOV a FH do vlastní školní praxe jsme navíc na celý model $\mathrm{FH}$ při BOV pohlíželi z perspektivy ideálně zrealizované výuky. Takto je třeba pohlížet i na dva př́iklady výukových bloků, které teoretický model ilustrují: v běžné praxi se některé zde popisované kroky nebo některé jejich kombinace jednoduše nezrealizují.

Pro začlenění FH do schématu pro badatelský cyklus jsme jako výchozí koncept zvolili model ESRU (Ruiz-Primo \& Furtak, 2006). Ten byl sice vytvořen pouze pro interakce on-the-fly, ale práce s ním nám ukázala, že poměrně jednoduchou úpravou $\mathrm{z}$ něj lze vytvořit model, který zahrnuje i vrstevnické hodnocení a diskusi se žáky ve třídě. Stačí vyčlenit velká písmena jako kódy pro činnosti učitele a malá písmena jako kódy pro činnosti žáků, významy kódů mohou zůstat v podstatě nezměněny:

E, e = vyvolání interakce

$S, s=$ reakce

$\mathrm{R}, \mathrm{r}=$ rozpoznání reakce

$\mathrm{U}, \mathrm{u}=$ užití zjištěných informací

Taková úprava umožňuje přiléhavě kódovat i výukové situace, ve kterých se různé metody $\mathrm{FH}$ navzájem prolínají. Zároveň je možné obecně říci, že při vrstevnickém hodnocení převažují v kódování malá písmena a při hodnocení on-the-fly velká písmena. Náš nový model budeme nazývat double:ESRU.

Pro konkrétní badatelské cykly jsme pak u každého jejich kroku posoudili, které činnosti související s FH v daném kroku mohou nastat. Př́ślušnému kroku jsme pak přiřadili odpovídající sadu kódů $\mathrm{z}$ modelu double:ESRU.

\section{Model výukového bloku s badatelskou úlohou}

Schéma modelu BOV s FH jsme se pokusili co nevíce zpřehlednit. Proto jsme ho

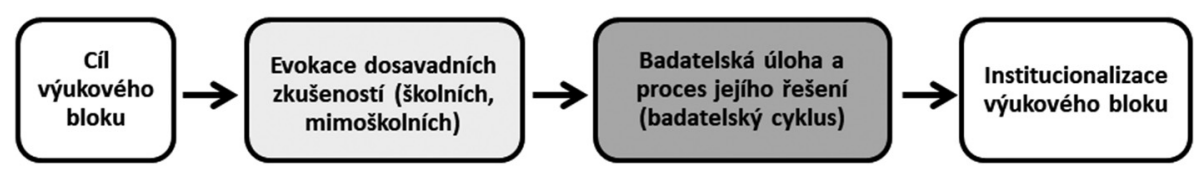

Obr. 3. Schéma modelu výukového bloku s badatelskou úlohou 
nejprve rozfázovali do dvou úrovní. První úroveň představuje celková struktura výukového bloku (obr. 3), druhou úroveň pak tvoří rozpracování dvou jejích položek do dílčích schémat: položky Evokace dosavadních zkušeností (obr. 4) a položky Badatelská úloha a proces jejího řešení (obr. 5).

Položka Evokace dosavadních zkušeností (obr. 4) má motivační aspekt a zároveň slouží $\mathrm{k}$ ověření si aktuálního stavu těch znalostí žáků, které budou nezbytné pro řešení badatelské úlohy. $\mathrm{V}$ ideálním př́padě má evokace podobu otevřené nebo strukturované diskuse, přičemž otázky a odpovědi mohou být jak nižší, tak vyšší kognitivní náročnosti, otevřené i uzavřené.

Položka Badatelská úloha a proces jejího řešení (obr. 5) sleduje samotný proces řešení vybrané badatelské úlohy. Při tvorbě dílč́iho schématu modelu badatelské úlohy a jejího řešení nás analýza jednotlivých kroků procesu dovedla ke dvěma stále se opakujícím činnostem, které mohou být součástí téměr libovolného kroku schématu:

- doptávání jako více či méně skrytá žádost žáka o radu nebo objasnění;

- diskuse nad názorem (žáka, učitele).

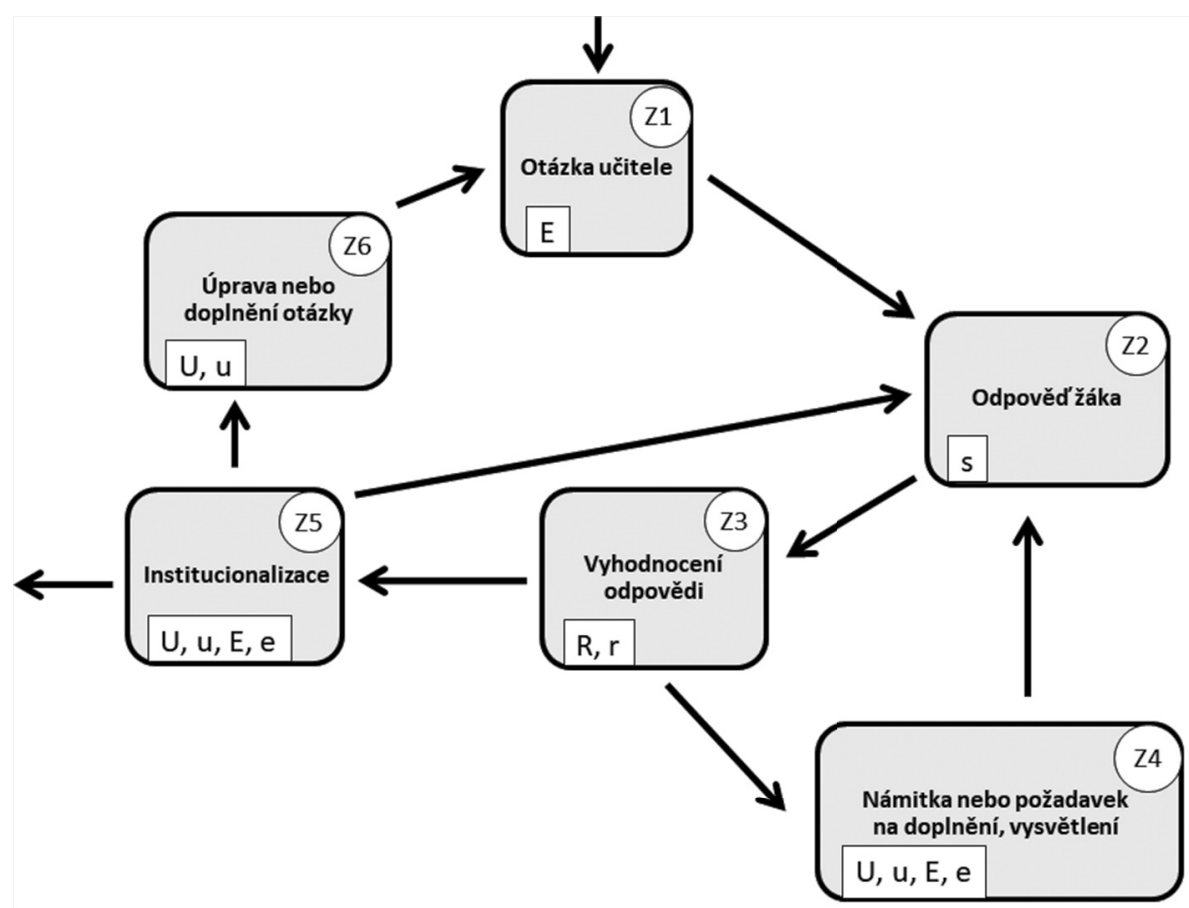

Obr. 4. Schéma modelu evokace dosavadních zkušeností 
Tyto dvě činnosti jsme tedy ze schématu řešení badatelské úlohy vyčlenili a vytvořili pro ně vlastní schémata třetí úrovně (doptávání - obr. 6, diskuse nad názorem - obr. 7). Stejně jako při evokaci mohou být otázky a odpovědi při doptávání nebo diskusi nad názorem jak nižší, tak vyšší kognitivní náročnosti, otevřené i uzavřené.

V každém dílčím schématu druhé a třetí úrovně mají jednotlivé kroky (dlaždice) přidělen rozlišovací kód uvedený $\mathrm{v}$ pravém horním rohu dlaždice $\mathrm{v}$ bílém kruhu. V levém dolním rohu jsou v bí- lém obdélníku výčtem uvedeny všechny související kódy modelu double:ESRU. $\mathrm{Na}$ schémata třetí úrovně můžeme kdykoli vybočit z kterékoli dlaždice schématu na obrázku 5 (kromě B1), a to i opakovaně nebo kombinovaně (tj. např́íklad v kombinaci doptávání - diskuse nad názorem - doptávání).

Nejdůležitější součástí celého modelu je schéma badatelského cyklu (obr. 5), na který žáky připravovaly činnosti náležející schématu evokace (obr. 4). Schéma badatelského cyklu začíná zadáním badatelské úlohy učitelem, po kterém následuje analýza

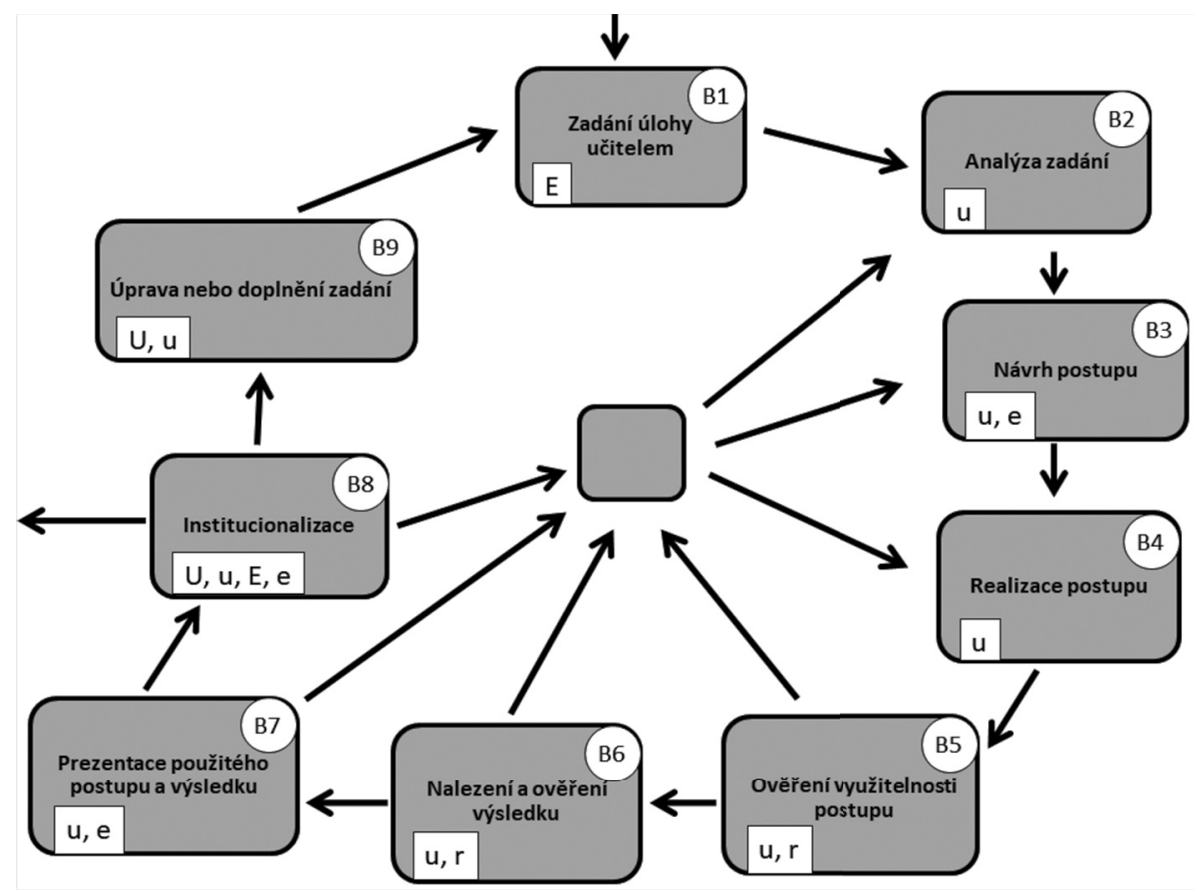

Obr. 5. Schéma modelu řešení badatelské úlohy; prostřední čtvercová dlaždice nemá kód, je to jen graficky znázorněná křižovatka bez obsahu 
zadání této úlohy. Analýza zadání je vstupem do řešení úlohy, žák si při ní uvědomí, co se v zadání úlohy dozvěděl, co má řešit. Návrh postupu řešení vychází z žákových zkušeností, které mohou být školní (napry. zkušenost $\mathrm{s}$ řešením podobných úloh), ale i mimoškolní (napřr. zkušenost s praktickou činností, která s úlohou souvisí). Dalším krokem badatelského cyklu je realizace postupu - fáze, při níž žák uskutečňuje to, co si naplánoval v předchozím kroku. V praxi se často stává, že žák nenaplánuje celý postup řešení. Na počátku má jen nápad, se kterým zahájí řešení, a čeká, co se stane. Ověření využitelnosti postupu je průběžnou součástí realizace postupu. Žák odhaduje, zda zvolený postup je realizovatelný (např. z hlediska časové náročnosti, potřebných znalostí, podmínek, řešitelnosti), zda tímto postupem dostává „rozumné“ výsledky, konfrontuje mezivýsledky se za- dáním úlohy. Nalezení a ověrení výsledku je posledním krokem řešení úlohy. $V$ určité chvíli se žák rozhodne, že nalezený výsledek vyhovuje zadání a je výsledkem konečným. Ve školních podmínkách pak často žáci prezentují svá různá řešení úlohy (různé postupy, výsledky), nabízejí je spolužákům a učiteli $\mathrm{k}$ diskusi. Institucionalizací může být celý badatelský cyklus uzavřen. Výsledky bádání nemusí být po diskusi ve třídě, která se rozbíhá různými směry, jasné všem žákům. A tak je dobré, když učitel na konci diskuse jasně a přehledně shrne, co je výsledkem činnosti žáků, a objevené poznatky tak institucionalizuje. Někdy se učitel rozhodne, že odebráním některých podmínek nebo přidáním dalších podmínek nebo obměnou úlohy vytvoří navazující úlohu, která je s původní úlohou spojená například tématem, prostředím, řešitelským postupem.

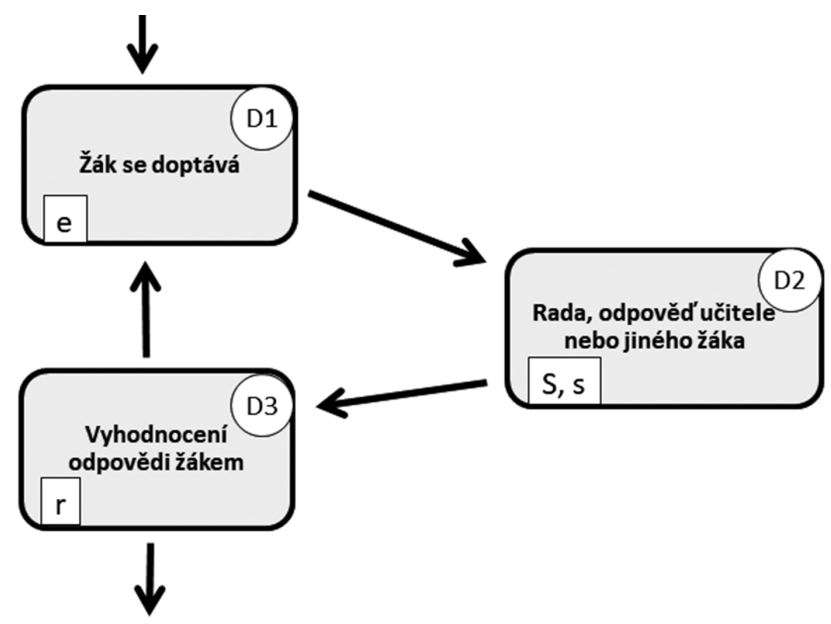

Obr. 6. Schéma procesu doptávání 


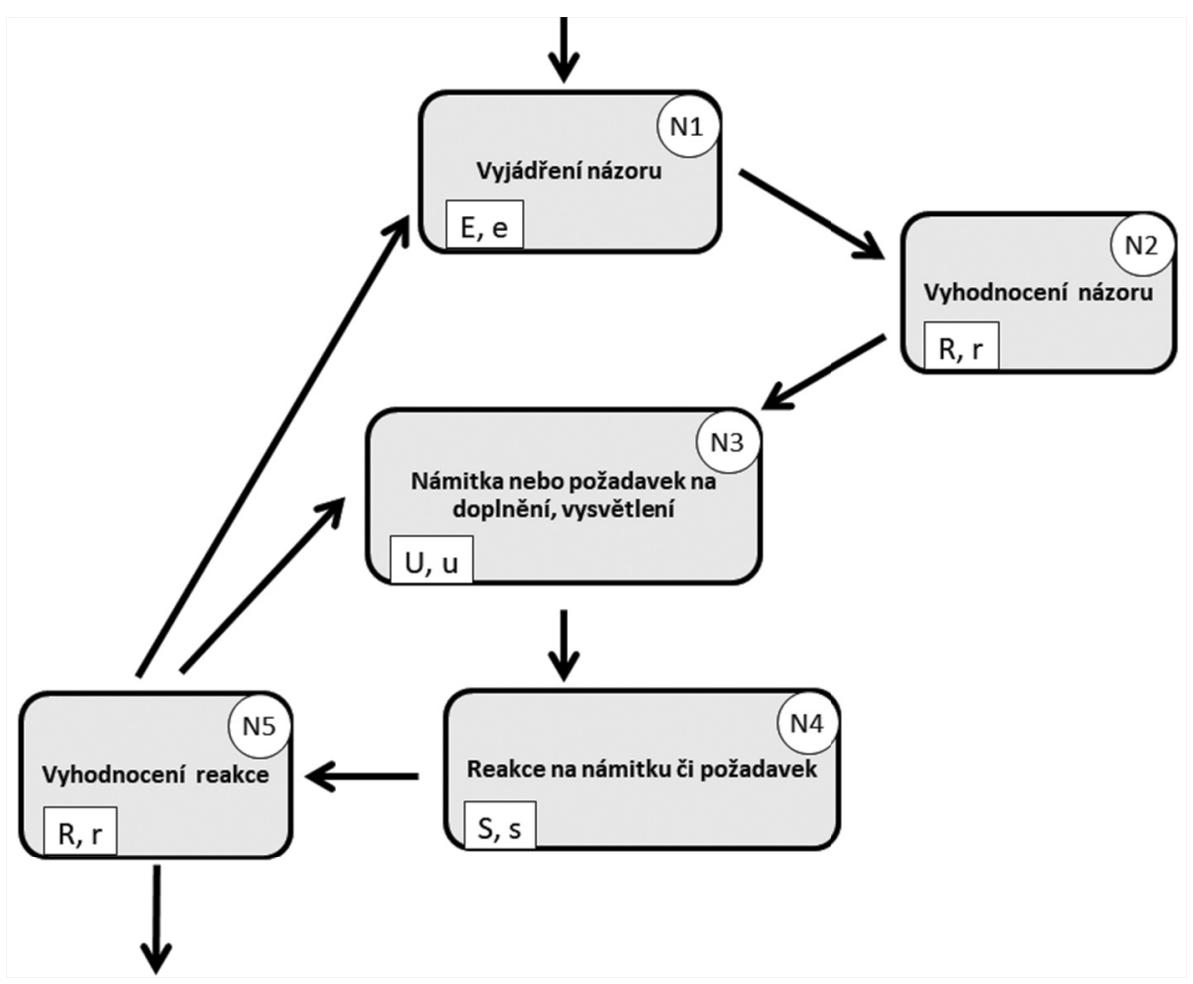

Obr. 7. Schéma diskuse nad názorem

\section{ILUSTRAČNÍ PŘÍKLADY}

Výše uvedený model FH při BOV a možnosti jeho využití ilustrujeme prostřednictvím dvou virtuálních výukových bloků s badatelskou úlohou. První blok je matematický, druhý př́rodopisný. Oba bloky jsou virtuální v tom smyslu, že jednotlivé části v nich uvedených dialogů jsou sice přepisy reálných situací z výuky, ale tyto situace se neodehrály během jedné vyučovací jednotky. Do jednoho spo- lečného bloku jsme tyto části sesadili tak, aby pomohly lépe ilustrovat funkci schémat $\mathrm{z}$ obrázků 4-7 $\mathrm{v}$ jejím plném rozsahu a aby zároveň naznačily možný ideální způsob realizace dané badatelské úlohy.

Průběh výukových bloků je zaznamenán formou grafických přepisů, jejichž elektronická verze je př́lohou tohoto př́spěvku. Přepisy mají podobu tabulek $s$ bublinovými rozhovory (tabulky P-1 až P-4), přičemž v každé tabulce jsou ve sloupci „BOV“ uvedeny zkratky 

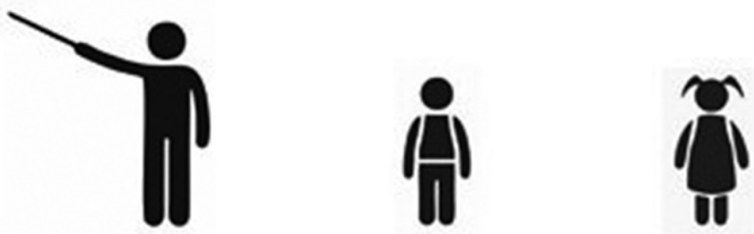

Obr. 8. Ikony pro učitele (vlevo) a žáky (uprostřed, vpravo)

příslušných kroků z dílčích schémat (tj. z obrázků 4-7) a ve sloupci „FH“ příslušné kódy modelu double:ESRU pro FH. Takto upravené přepisy umožňují jednoznačné provázání činností učitele a žáků $s$ jednotlivými kroky procesu BOV, a také poskytují přehled o podobě prípadné realizace $\mathrm{FH}$.

Zapojení učitele a žáků je v tabulkách P-1 až P-4 vyznačeno prostřrednictvím ikon (obr. 8), přičemž změna žákovské ikony vždy znamená změnu žáka. $V$ tabulce P-1 jsou tak příspěvky na řádcích 2 a 3 od různých žáků. $V$ tabulce $\mathrm{P}-2$ jsou příspěvky na řádcích 3 a 5 od stejného žáka, ale príspěvky na řádcích 5 a 6 od různých žáků. Příspěvky uvedené na řádcích 5 a 9 mohou, ale nemusí být od stejného žáka.

\section{Ilustrační př́íklad realizace modelu - matematická úloha}

Cílem tohoto výukového bloku je posílit představu o významu řádu číslice $\mathrm{v}$ desítkové soustavě a o skutečné velikosti souborů s velkým počtem prvků. Jako prostředek $\mathrm{k}$ dosažení tohoto cíle byla vybrána badatelská úloha „Jak velká jsou velká čísla?", při které žáci zkoumají čas potřebný pro vyjmenování řady čísel od jedné do milionu. Pro zdárné řešení této úlohy je nutné se orientovat $\mathrm{v}$ desítkové soustavě a umět čísla od jedné do milionu seřadit a správně pojmenovat, a tak v rámci prrípravy je vhodné provést evokaci založenou na úloze „Jak se jmenují velká čísla?“.

Přepis úvodní části virtuální realizace evokační úlohy je uveden $\mathrm{v}$ tabulce P-1. Po této realizaci může následovat několikrát smyčka složená z kroků $Z 1$ až Z6, která u posledního prŕíkladu skončí na kroku Z5, jenž může být obsáhlejší (shrnutí za celou úlohu, zopakování principu řádů $\mathrm{v}$ desítkové soustavě a názvů relevantních řádů). Šipka od kroku Z5 ke kroku Z2 nebyla v tabulce P-1 využita, ale mohlo by na ni dojít, kdyby úloha měla více řešení nebo více postupů řešení (jedno řešení už bylo představeno, učitel se ptá po dalších), nebo kdyby žák i po kroku Z4 odpověděl chybně (učitel může $\mathrm{v}$ rámci kroku $\mathrm{Z5}$ poskytnout vodítko a znovu se na téhož žáka obrátit).

Po evokaci následuje samotná badatelská úloha a její řešení; přepis této virtuální realizace je uveden v tabulce P-2. Žáci př́i ní nejprve zkoušejí všechna čísla vyjmenovat a čas měřit na stopkách, ale 
Tab. P-1. Přepis evokace zprostředkované úlohou „Jak se jmenují velká čísla?“

\begin{tabular}{|c|c|c|c|}
\hline & & BOV & FH \\
\hline 1 & $\begin{array}{l}\text { Jak sejmenuje toto cislo? } \\
{\left[\begin{array}{l}\text { piśsečislo ona tabuli] } \\
238569\end{array}\right.}\end{array}$ & Z1 & E \\
\hline 2 & $\begin{array}{l}\text { Dvě stě třicet osm pět set } \\
\text { Šedesát devět }\end{array}$ & Z2 & $\mathbf{s}$ \\
\hline 3 & To není dobře. & $\mathbf{Z 3}$ & $\mathbf{r}$ \\
\hline 4 & & $\mathbf{Z 3}$ & $\mathbf{R}$ \\
\hline 5 & Zkus to znovu. & Z4 & $\mathbf{U}, \mathbf{E}$ \\
\hline 6 & $\begin{array}{l}\text { Dvě stě třicet osm tisíc pět set } \\
\text { šedesát devět. }\end{array}$ & Z2 & $\mathbf{s}$ \\
\hline 7 & & $\mathrm{Z3}$ & $\mathbf{R}$ \\
\hline 8 & $\begin{array}{l}\text { Nesmime zapomi } \\
\text { tisice. }\end{array}$ & Z5 & U \\
\hline 9 & & Z6 & U \\
\hline 10 & $\begin{array}{l}\text { ak se jmenuje toto ćislo? } \\
{[\text { piše čislo } 3095023 \text { na tabuli] }}\end{array}$ & Z1 & E \\
\hline
\end{tabular}

zjištují, že to je př́liš časově náročné, a tak přistupují k řešení prostřednictvím výpočtu. Metodiku výpočtu průběžně upravují, aby lépe odpovídala realitě.

$\mathrm{V}$ procesu zaznamenaném $\mathrm{v}$ tabulce P-2 byla využita zpětná šipka od B5 k B3, když žáci zjistili, že jimi zvolený postup není z časových důvodů realizovatelný, pak zpětná šipka od B7 k B3, kdy žáci po upozornění učitelem objevili chybu $\mathrm{v}$ metodice svého postupu, a zpětná šipka od B6 k B4, když učitel požadoval vhodnější vyjádření nalezeného výsledku. Nakonec byla ještě jednou využita zpětná šipka od B7 k B3, opět kvůli chybě v metodice postupu. Šipka od kroku B6 ke kroku B2 v tabulce P-2 nebyla využita, ale došlo by na ni, kdyby např́iklad u postupu založeného na výpočtu vyšel výsledek, který není v souladu se zadáním, a tak by jeden z žáků navrhl opětovné prostudování zadání, jestli se na něco nezapomnělo. Šipka od kroku B8 ke kroku B3 může být využita, pokud úloha má více řešení nebo více postupů řešení (jedno řešení už bylo představeno a shrnuto, učitel se ptá po dalších), nebo pokud by žák v kroku B7 představil chybný postup a nápravě nepomohla ani diskuse (učitel by tak v rámci kroku B8 poskytl vodítko a nasměroval žáka $\mathrm{k}$ úpravě původního postupu nebo k navržení zcela jiného postupu).

$\mathrm{V}$ rámci kroku B9 mohou být navrženy různé úpravy zadání úlohy: změna z milionu na miliardu nebo na tisíc, dodání praktické dimenze („Kolik obyvatel má Praha, Česká republika, Evropa...? Jak dlouho by se při společném nástupu představovali? Jak daleko je to z Prahy do Paříže, San Franciska, Sydney? Jak daleko je to ze Země na Měsíc, Mars, Slunce?").

Z pohledu Rámcového vzdělávacího programu pro základní vzdělávání (MŠMT, 2017) je možné tento blok s badatelskou úlohou zařadit již do druhého období prvního stupně základní školy; matematický obsah bloku souvisí s tématy Číslo a početní operace (aplikace 


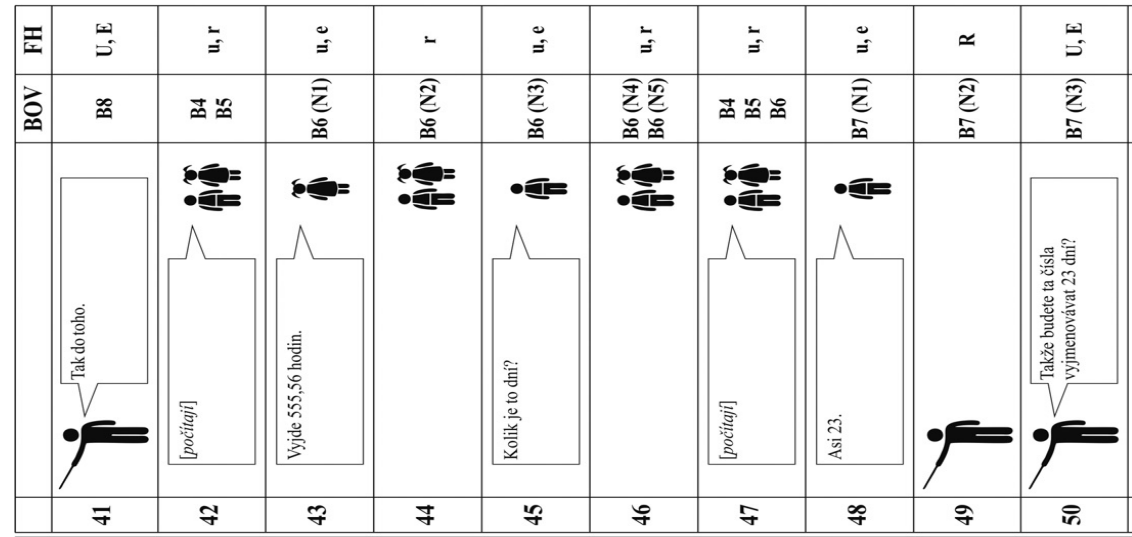

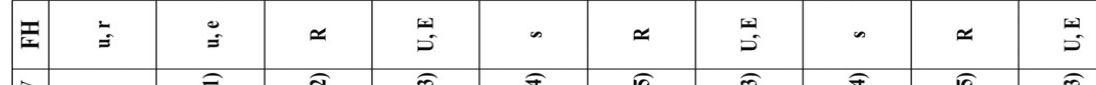

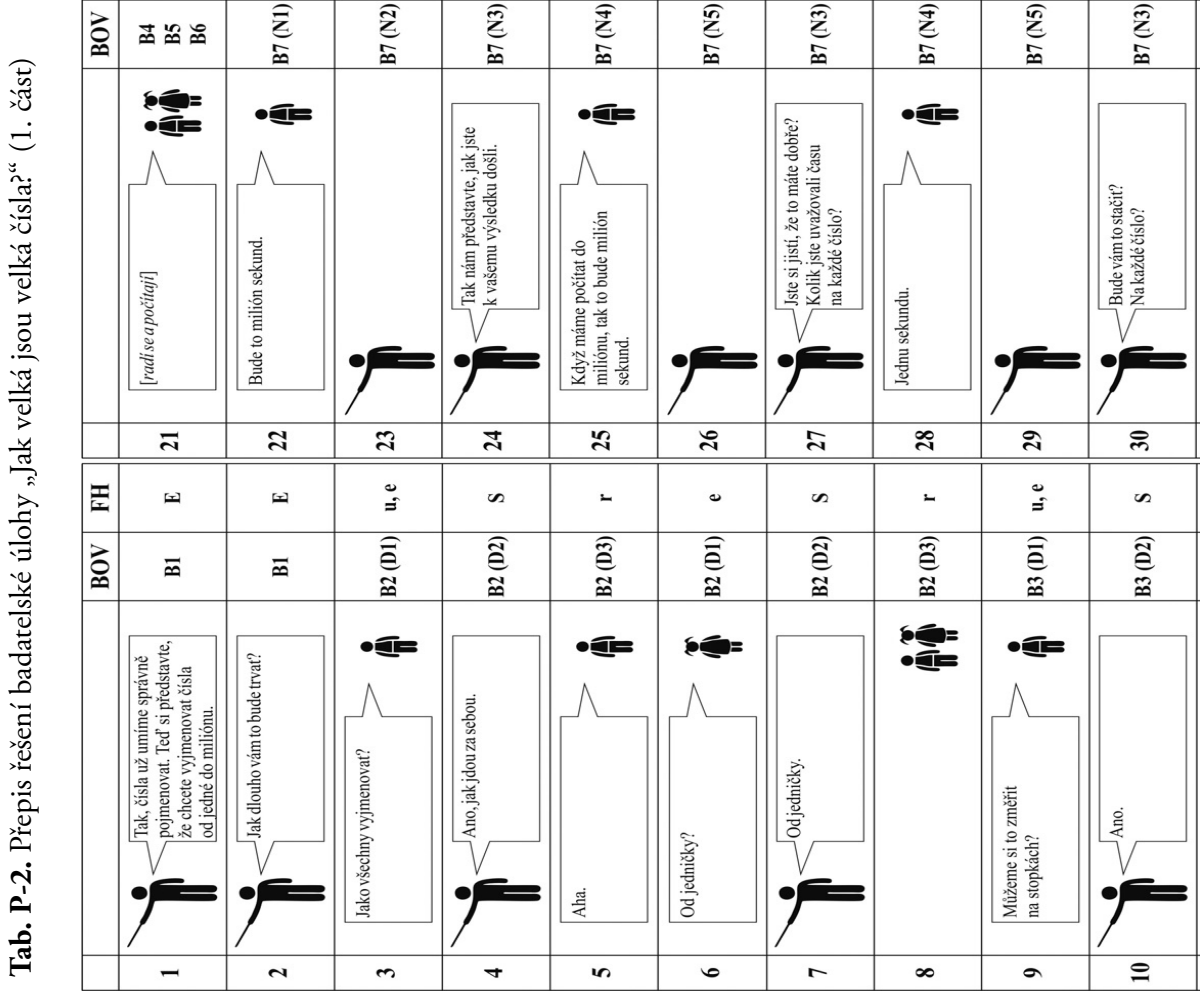




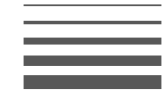

\begin{tabular}{|c|c|c|c|c|c|c|c|c|c|}
\hline$n$ & $\simeq$ & $\begin{array}{l}51 \\
0\end{array}$ & $\infty$ & $\infty$ & $\infty$ & $\infty$ & n & in & $=$ \\
\hline 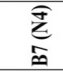 & 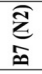 & $\sum_{\hat{\infty}}^{\widehat{\hat{n}}}$ & 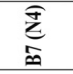 & 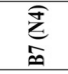 & 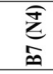 & 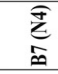 & 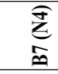 & $\sum_{\bar{\infty}}^{\bar{n}}$ & $\cong$ \\
\hline $\begin{array}{l}\bullet I= \\
\Lambda\end{array}$ & & 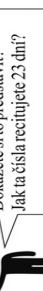 & $\begin{array}{l}\cdot I= \\
\Lambda\end{array}$ & 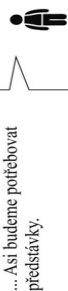 & 65 & I & 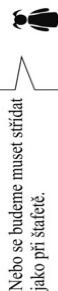 & & 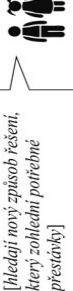 \\
\hline $\bar{n}$ & กี & in & it & in & in & in & $i$ & ही & 8 \\
\hline
\end{tabular}

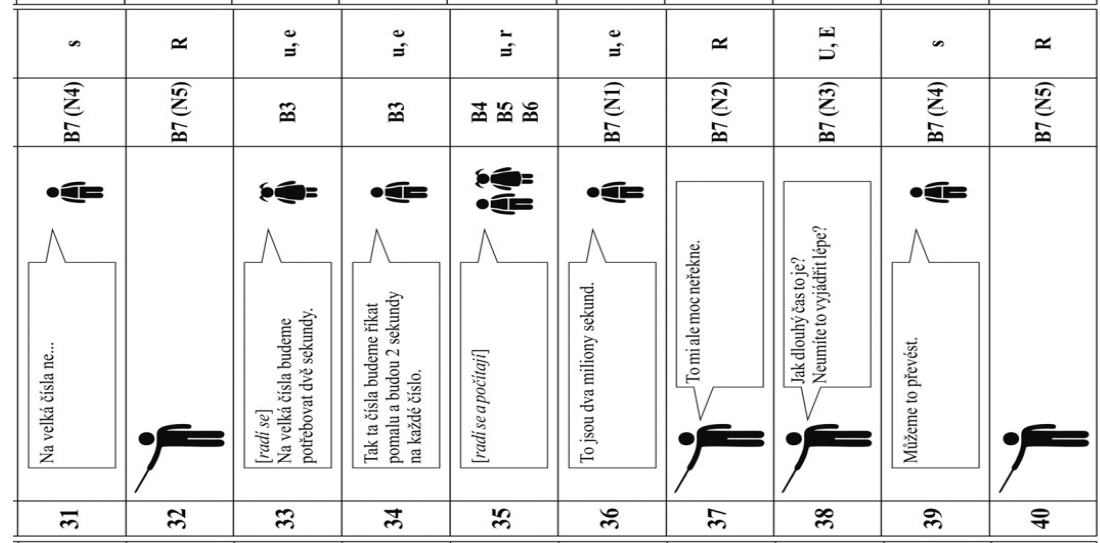

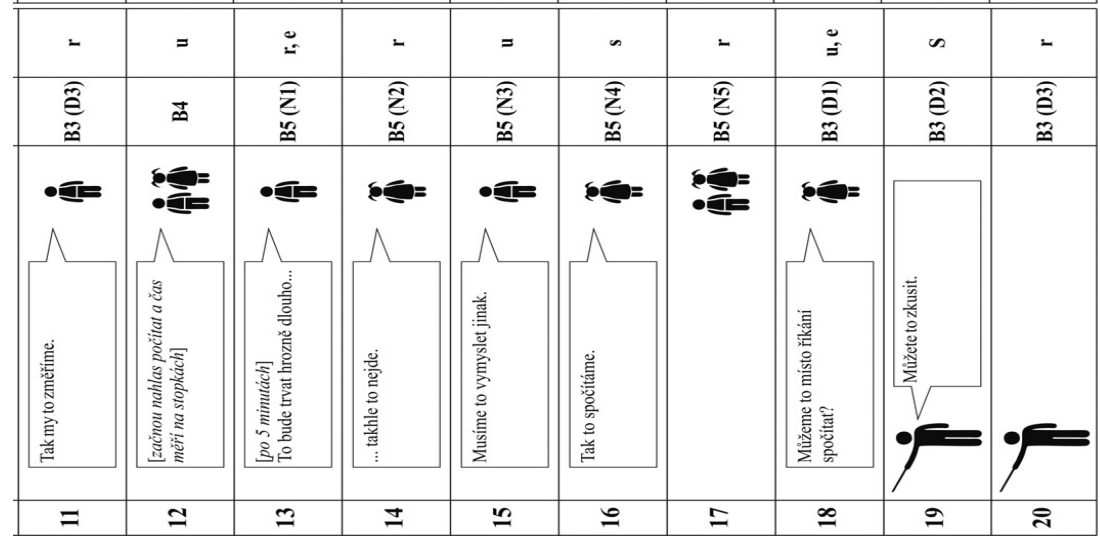


početních operací v oboru přirozených čísel), Práce s daty (převody jednotek času) a Nestandardní aplikační úlohy. Později na prvním stupni je možné celý blok využít jako evokační před výkladem odvození desetinných čísel. Na druhém stupni základní školy je možné blok využít jako výukovou jednotku nabízející nový pohled na dříve probírané a žáky již osvojené záležitosti spadající pod téma Číslo a proměnná, ale také v tématu Závislosti, vztahy a práce s daty (matematizace jednoduchých reálných situací $s$ využitím funkčních vztahů) - v takovém případě se na konec procesu řešení stávající badatelské úlohy (za krok B8) přidá krok Doplnění zadání (B9) spočívající v požadavku učitele, aby žáci v souladu s jimi použitou metodikou experimentu našli obecné vyjádření funkční závislosti času na zvoleném velkém čísle.

\section{Ilustrační př́íklad realizace modelu - přírodopisná úloha}

Cílem prýrodopisného výukového bloku je uvědomění si souvislosti mezi vybranými faktory a hodnotami dechové frekvence člověka. Evokační fáze je zprostředkována úlohou "Co může ovlivňovat rychlost dýchání́?", při které je žákům předložen seznam šesti faktorů (fyzická aktivita, pohlaví, životní styl, nadmořská výška, denní doba, nervozita a stres), a žáci vybírají, které faktory ovlivňují frekvenci dýchání. Následně žáci řeší badatelskou úlohu „Co a jak ovlivňuje rychlost dýchání?", při které navrhují vlastní pokus, v němž vliv jimi vybraného faktoru prakticky oveř́í.
Přepis virtuální realizace evokace je uveden $v$ tabulce P-3. Na rozdíl od matematické úlohy zde nebyl využit krok Z6 (úprava nebo doplnění

Tab. P-3. Přepis evokace zprostředkované úlohou „Co ovlivňuje rychlost dýchání?“"

\begin{tabular}{|c|c|c|c|}
\hline & & BOV & FH \\
\hline 1 & $\begin{array}{l}\text { Které z faktorů podle vás } \\
\begin{array}{l}\text { ovlivn̆ují rychlost dýchání? } \\
\text { Prohlédněte si seznam } \\
\text { v pracovnim listu. }\end{array}\end{array}$ & Z1 & $\mathbf{E}$ \\
\hline 2 & $\begin{array}{l}\text { [studuji seznam] } \\
\text { Fyzická aktivita, nervozita } \\
\text { a stres. }\end{array}$ & $\mathbf{Z 2}$ & $\mathbf{s}$ \\
\hline 3 & $\begin{array}{l}\text { Já myslím, že ještě životní } \\
\text { styl. }\end{array}$ & Z3 & $\mathbf{r}$ \\
\hline 4 & & $\mathbf{Z 3}$ & $\mathbf{R}$ \\
\hline 5 & na néjaký faktor? & Z4 & $\mathbf{U}, \mathbf{E}$ \\
\hline 6 & $\begin{array}{l}\text { Co nadmořská výška? Když } \\
\text { jsme na horách, tak dýcháme } \\
\text { jinak. }\end{array}$ & $\mathbf{Z 2}$ & $\mathbf{s}$ \\
\hline 7 & du & Z3 & $\mathbf{R}$ \\
\hline 8 & $\begin{array}{l}\text {... a dýchás rychle } \\
\text { pomaleji? }\end{array}$ & Z4 & $\mathbf{U}, \mathbf{E}$ \\
\hline 9 & Pomaleji. & $\mathbf{Z 2}$ & $\mathbf{s}$ \\
\hline 10 & na chybnou odpovéd] & $\mathbf{Z 3}$ & $\mathbf{R}$ \\
\hline 11 & $\begin{array}{l}\text { Takže jsme vybrali fyzickou } \\
\text { aktivitu, životní styl, nervozitu, } \\
\text { stres a nadmořskou výšku. }\end{array}$ & Z5 & $\mathbf{U}$ \\
\hline 12 & $\mathrm{Ne}$, rychleji! & $\mathbf{Z 2}$ & $\mathbf{s}$ \\
\hline 13 & výšku... & $\mathbf{Z 3}$ & $\mathbf{R}$ \\
\hline 14 & $\begin{array}{l}\text {...poradne prozkoumame } \\
\text { v zimě, až pojedeme } \\
\text { na lyžařský kurz. }\end{array}$ & Z5 & $\mathbf{U}, \mathbf{E}$ \\
\hline
\end{tabular}


Tab. P-4. Přepis úvodní části řešení badatelské úlohy „Co a jak ovlivňuje rychlost dýchání?““

\begin{tabular}{|c|c|c|c|c|c|c|c|}
\hline & & BOV & FH & & & BOV & FH \\
\hline 1 & $\begin{array}{l}\text { Řekli jsme si, že fyzická } \\
\text { aktivita, životní styl, nervozita, } \\
\text { stres a nadmorská výška } \\
\text { ovlivñuji rychlost dýchání. }\end{array}$ & B1 & $\mathbf{E}$ & 17 & $\begin{array}{l}\text { Jako dělat stejnou činnost - } \\
\text { třeba dřepy. }\end{array}$ & B3 (N4) & $\mathbf{s}$ \\
\hline 2 & $\begin{array}{l}\text { Jaký faktor si vyberete } \\
\text { pro svúj dnešní pokus? } \\
\text { Jak budete postupovat? }\end{array}$ & B1 & $\mathbf{E}$ & 18 & & B3 (N5) & $\mathbf{R}$ \\
\hline 3 & [radi se, zapisuji do protokolu] & B2 & $\mathbf{u}$ & 19 & Iste si jistí, že to tak & B3 (N3) & $\mathbf{U}, \mathbf{E}$ \\
\hline 4 & $\begin{array}{l}\text { My jsme zvolili fyzickou } \\
\text { aktivitu, že změní, jak } \\
\text { dýcháme. }\end{array}$ & B3 (N1) & $\mathbf{u}, \mathbf{e}$ & 20 & $\begin{array}{l}\text { Nem̌rli byste uvést ještte něco, } \\
\text { kdyby to po vás chtěl někdo } \\
\text { zopakovat? }\end{array}$ & B3 (N3) & $\mathbf{U}, \mathbf{E}$ \\
\hline 5 & $\begin{array}{l}\text { Budeme dýcháni měřit v klidu } \\
\text { a při zátěži. }\end{array}$ & B3 (N1) & $\mathrm{u}, \mathbf{e}$ & 21 & $\begin{array}{l}\text { [přemýsili] } \\
\text { Kolik těch dřepů má být. }\end{array}$ & B3 (N4) & $\mathbf{s}$ \\
\hline 6 & $\begin{array}{l}\text { Dobře, vybrali jste ověření } \\
\text { fyzické vlivu fyzické zátěže } \\
\text { na frekvenci dýcháni. }\end{array}$ & B3 (N2) & $\mathbf{R}$ & 22 & A jak rychle je máme dělat. & B3 (N4) & $\mathbf{s}$ \\
\hline 7 & měřit v klidu a při zátěži. & B3 (N2) & $\mathbf{R}$ & 23 & & B3 (N5) & $\mathbf{R}$ \\
\hline 8 & & B3 (N3) & $\mathbf{U}, \mathbf{E}$ & 24 & & B3 (N3) & $\mathbf{U}, \mathbf{E}$ \\
\hline 9 & My budeme dělat dřepy. & B3 (N4) & $\mathbf{s}$ & 25 & \begin{tabular}{|l} 
[radise $]$ \\
Kdy budeme měřit...
\end{tabular} & B3 (N4) & $\mathbf{s}$ \\
\hline 10 & My kliky, to je těžši! & B3 (N4) & s & 26 & Na začátku a a na konci. & B3 (N4) & $\mathbf{s}$ \\
\hline 11 & & B3 (N5) & $\mathbf{R}$ & 27 & & B3 (N5) & $\mathbf{R}$ \\
\hline 12 & & B3 (N3) & $\mathbf{U}, \mathbf{E}$ & 28 & & B3 (N3) & $\mathbf{U}, \mathbf{E}$ \\
\hline 13 & \begin{tabular}{|l} 
[radise $]$ \\
Asine.
\end{tabular} & B3 (N4) & s & 29 & $\begin{array}{l}\text { Jako stejným způsobem } \\
\text { a stejné dlouho. }\end{array}$ & B3 (N4) & $\mathbf{s}$ \\
\hline 14 & & B3 (N5) & $\mathbf{R}$ & 30 & $\begin{array}{l}\text { v protokolech a mûžete se } \\
\text { pustit do pokusu. }\end{array}$ & B3 (N5) & $\mathbf{R}$ \\
\hline 15 & $\begin{array}{l}\text { Tak řekněte, jak byste to } \\
\text { prováděli. }\end{array}$ & B3 (N3) & $\mathbf{U}, \mathbf{E}$ & 31 & [upravuji protokoly] & B3 & u \\
\hline 16 & Musime to dělat všichni stejně. & B3 (N4) & $\mathbf{s}$ & 32 & [realizuji pokus] & B4 & $\mathbf{u}$ \\
\hline
\end{tabular}


otázky, obr. 4), nebot ke shrnutí potřebných znalostí žáků došlo již $\mathrm{v}$ rámci kroků $Z 1-Z 5$, během postupného upřesňování odpovědí žáků na otázku položenou učitelem. V první části evokace (řádky $1-5 \mathrm{v}$ tabulce P-3) směřoval učitel $\mathrm{k}$ žákům požadavek na doplnění (Z4), aby žáky nave$\mathrm{dl} \mathrm{k}$ upřesnění předchozí odpovědi. Tento krok ale učitel záměrně vypustí v následující části (řádek 10), kdy ponechává chybnou odpověd' žáků bez povšimnutí a přesouvá se $\mathrm{k}$ institucionalizaci (Z5), přičemž žáci po nějaké době chybu v předchozí odpovědi sami identifikují (Z2). Kdyby k této identifikaci včas nedošlo, mohl by učitel využít krok Z6 a úpravou nebo doplněním otázky žáky $\mathrm{k}$ rozpoznání chyby navést.

Přepis virtuální realizace badatelské př́rodopisné úlohy je uveden $\mathrm{v}$ tabulce P-4. Také zde se průchod schématem modelu řešení badatelské úlohy (obr. 5) pro vybranou přírodopisnou úlohu liší od ilustrační matematické úlohy. Při realizaci př́rodopisné úlohy nebyla využita zpětná šipka od B5 k B3 ani od B7 k B3, nebot učitel do procesu vyjasnění si správné metodiky průběžně nenásilně vstupoval a žáky směřoval $\mathrm{k}$ tomu, aby si samostatně uvědomili slabé stránky svého postupu a došli ke správné metodice provedení pokusu. Tuto strategii je možné pozorovat již ve fázi zadání badatelské úlohy (B1) a návrhu postupu (B3), kde žáci doplňují vlastní odpovědi (kroky N1-N5) a učitel působí jako facilitátor diskuse. V závěrečném kroku B3 (N5) učitel diskusi uzavírá a nechává žákům prostor pro zaznamenání si všech informací do protokolů. Krokem B4 začíná samostatná práce žáků, kteří si vyzkouší provedení experimentu podle vlastního návrhu, a plynule tak prochází kroky B5-B7.

Z pohledu Rámcového vzdělávacího programu pro základní vzdělávání (MŠMT, 2017) je možné tento blok $s$ badatelskou úlohou zařadit nejčastěji do osmého ročníku (podle strukturování př́íslušného Školního vzdělávacího programu) v rámci vzdělávací oblasti Člověk a př́roda, do vzdělávacího oboru Přírodopis a vzdělávacího obsahu Biologie člověka (učivo anatomie a fyziologie, popř. životní styl). Do jisté míry by blok mohl být využit i v oblasti Člověk a zdraví, konkrétně ve Výchově ke zdraví při probírání učiva vztahujícího se ke zdravému způsobu života a $\mathrm{k}$ péči o zdraví.

\section{DISKUSE A ZÁVĚR}

V tomto př́spěvku jsme představili podstatu, podobu a možné praktické využití teoretického modelu pro interakce při $\mathrm{FH}$ v rámci $\mathrm{BOV}$ ve dvou vybraných předmětech: matematice a přírodopisu. Nabídli jsme tak přístup $\mathrm{k}$ problematice BOV, který je spíše ojedinělý tím, že je pro př́rodopis a matematiku společný. $\mathrm{Z}$ pohledu $\mathrm{FH}$ model vychází z kódování ESRU modelu pro analýzu interakcí při poskytování okamžité zpětné vazby (Ruiz-Primo \& Furtak, 2006) uzpůsobeného tak, 
aby odlišoval činnosti učitele od činností žáků a aby umožňoval kódování interakcí při $\mathrm{FH}$ tvořeném libovolnou kombinací poskytování okamžité zpětné vazby, vrstevnického hodnocení a otevřené nebo strukturované diskuse se žáky ve trrídě. Tento nově vzniklý model pro kódování interakcí při FH nazýváme double:ESRU modelem. Samy autorky ESRU modelu ve svém př́spěvku (Ruiz-Primo \& Furtak, 2006) připouští, že jednotlivé fáze E-S-R-U nepokrývají celou problematiku FH pro BOV a nejsou dostatečně podrobné. Námi navrhovaný double:ESRU model nabízí žádané rozšíření a zpřesnění, které umožňuje přiléhavější analýzu odehrávajících se interakcí a přehlednější identifikaci jejich stěžejních míst.

$\mathrm{Z}$ pohledu $\mathrm{BOV}$ model pro $\mathrm{FH}$ při BOV vychází z badatelského cyklu (Anderson, 2002), který jsme rozložili do tři úrovní. Základní úrovní je celková struktura výukového bloku $s$ badatelskou úlohou spočívající ve vymezení cíle výukového bloku, evokaci dosavadních zkušeností žáků, badatelské úloze jako takové a $\mathrm{v}$ institucionalizaci výukového bloku. $\mathrm{Na}$ druhé úrovni je do jednotlivých kroků rozpracována struktura procesu evokace a struktura procesu řešení badatelské úlohy. Třetí úroveň tvoří dvě stále se opakující činnosti, které mohou nastat v libovolném okamžiku libovolné součásti badatelského cyklu: doptávání se a diskuse nad názorem. Schéma evokace dosavadních zkušeností a schéma procesu řešení badatelské úlohy jsou záměrně od sebe oddělena, protože každé z nich má jinou dynamiku: při evokaci se vyvolávají již osvojené znalosti a prožité zkušenosti, takže interakce jsou spíše krátké a rychlé, ale při řešení badatelské úlohy se od žáků očekává více samostatného přemýšlení, takže interakce jsou spíše delší (obsahují podrobnější popisy, vysvětlování apod.) a pomalejší (s většími přestávkami mezi nimi, během kterých žáci př̀mýšlí).

Rozložení badatelského cyklu do více úrovní a oddělení schématu pro evokaci od schématu pro řešení badatelské úlohy také považujeme za vhodnější z hlediska učitele, který začíná s implementací BOV a $\mathrm{FH}$ do své vlastní výuky. Kombinace BOV a FH je značně komplexní záležitostí, její rozdělení na různé úrovně a dílčí schémata takovému učiteli umožní postupné začleňování jednotlivých součástí BOV a FH: učitel může vyjít ze součásti (úrovně, schématu), která je mu nejbližší, ty další jednotlivě odděleně procvičovat a vše najednou implementovat až v okamžiku, kdy jsou jednotlivé dílčí součásti zvládnuty.

$\mathrm{V}$ neposlední řadě je možné dílčí součásti modelu pro $\mathrm{FH}$ při $\mathrm{BOV}$ využít i jednotlivě, při výuce, která nemusí být nutně vázána na BOV. Např́íklad evokační fázi nalezneme ve většině běžných vyučovacích hodin a double:ESRU model umožňuje její analýzu vzhledem k FH, i když hodina není badatelsky zaměřená. 
Jak jsme již uvedli, badatelské úlohy v př́rodopisu a matematice mají stejný cíl a princip, nicméně jejich pojetí se může výrazněji lišit. $\mathrm{V}$ př́rodopisu jsou často žáci vedeni k tomu, aby vyplňovali pracovní list, který je danou úlohou provází. Jedná se o usnadnění pro učitele i pro žáky samotné, pokud nemají s badatelskými aktivitami dostatečné zkušenosti. Na druhou stranu právě použití pracovního listu do jisté míry omezuje proces $\mathrm{FH}$, jelikož nedává tak velký prostor pro sdílení vlastních myšlenek, jejich kritické posuzování a otevřené diskutování mezi žáky. Zde prezentované schéma je jistým návodem, jak dělat badatelskou aktivitu s prvky FH bez pevné struktury (pouze $s$ užitím určitých opěrných bodů např́klad klíčových bodů diskuse) a zapisování si všech kroků do pracovního listu. Právě větší otevřenost a míra interakcí mezi žáky je v procesu $\mathrm{FH}$ žádoucí. Přes veškeré odlišnosti, které panují mezi matematickým a prírodo-

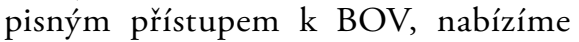
$\mathrm{v}$ tomto příspěvku společný komunikační model, který je možné využít ve výuce obou předmětů.

V letech 2013-2016 někteří autoři tohoto prŕspěvku spolupracovali na mezinárodním výzkumném projektu ASSIST-ME (Dolin \& Evans, 2018), který se zabýval FH při BOV $\mathrm{v}$ přírodovědných předmětech a matematice. Jedním z poznatků projektu bylo, že vybraní učitelé př́rodopisu a matematiky volali po př́kladech dobré praxe (Žlábková et al., 2020).
Domníváme se, že pokud by náš model pro $F H$ při BOV byl použit při analýze vybraných hodin, mohl by učitelům poskytnout dobrý návod, osnovu, jak řešit danou problémovou situaci. Lze říci, že by mohl na základě našich schémat a double:ESRU kódování vzniknout určitý „manuál“, jak využít např́íklad třídní diskusi k rozvoji $\mathrm{FH}$, jak ideálně reagovat na žáky při poskytování okamžité vazby apod. Samozřejmě, že primárně se zde prezentovaným modelem pro $\mathrm{FH}$ při BOV budou pracovat akademici, kteří vyučovací hodiny analyzují, ale podle našeho názoru jsou prezentovaná schémata poměrně jednoduchá a zorientuje se v nich i sám učitel. Další výhodu spatřujeme $\mathrm{v}$ možnosti použití modelu a jeho dílčích schémat i v pregraduální přípravě budoucích učitelů, kteří např́íklad s užitím videonahrávek výukových situací mohou identifikovat klíčová místa $\mathrm{v}$ zaznamenané diskusi, navrhovat alternativní přístupy $\mathrm{k}$ usměrnění diskuse či $\mathrm{k}$ navozování interakcí mezi aktéry videonahrávky.

Přestože $\mathrm{v}$ našich ilustračních příkladech nejsou použity reálné dialogy žáků, jedná se o věrohodné modely interakcí úzce založené na našich zkušenostech s realizací $\mathrm{FH}$ při $\mathrm{BOV}$, nebot́ části dialogů jsou přepisem reálných situací z výuky, jen se všechny neodehrály během jedné vyučovací jednotky. Samozřejmě si uvědomujeme, že reálná diskuse nebude probíhat takto ideálně, nicméně hlavní pod- 
stata celého procesu zůstává stejná. Námi představené ilustrační prŕklady tedy nejsou obrazem reality, jsou ale jakýmsi virtuálním maximalistickým př́kladem dobré praxe. Jako ilustrační jsme záměrně vybírali př́klady, které se od sebe liší způsobem průchodu jednotlivými schématy komunikačního modelu, a tak jako celek nabízejí komplexnější představu o různých možných podobách realizace $\mathrm{FH}$ při BOV. Matematický příklad např́iklad představuje způsob řešení badatelské úlohy, při kterém učitel nechává žáky provádět experiment $s$ nerealizovatelnou nebo nesprávnou metodikou a čeká, až žáci sami slabé stránky této metodiky objeví, zatímco př́rodovědný prŕḱlad ukazuje, jak učitel může žáky nenápadně směrovat $\mathrm{k}$ tomu, aby si slabé stránky navrhovaných metodik uvědomili ještě před samotnou realizací experimentu.

Souhrnem lze říci, že zde prezentovaný model pro FH při BOV nabízí pedagogickému výzkumu nástroj pro podrobnou přiléhavou analýzu formativního hodnocení při badatelsky orientované výuce, učitelům a budoucím učitelům nabízí nástroj pro podporu implementace formativního hodnocení a badatelského př́stupu do jejich vlastní výuky. Vizualizace propojení obou př́stupů a nezávislost modelu na školním předmětu by měla napomoci porozumět možnostem, které formativní hodnocení při badatelsky orientované výuce nabízí.

\section{Literatura}

Anderson, R. (2002). Reforming science teaching: What research says about inquiry. Journal of Science Teacher Education, 13(1), 1-12.

Artigue, M., \& Blomhøj, M. (2013). Conceptualizing inquiry-based education in mathematics. ZDM Mathematics Education, 45, 797-810.

Barrows, H. S., \& Tamblyn, R. M. (1980). Problem-based learning: An approach to medical education. New York: Springer.

Black, P., Harrison, C., Lee, C., Marshall, B., \& Wiliam, D. (2004). Working inside the black box: Assessment for learning in the classroom. Phi Delta Kappan, 86(1), 8-21.

Black, P., \& Wiliam, D. (1998). Assessment and classroom learning. Assessment in Education: Principles, Policy \& Practice, 5, 7-74.

Bransford, J. D., Brown, A. L., \& Cocking, R. R. (2000). How people learn: Brain, mind, experience, and school. Washington, D. C.: National Academy Press.

Bruner, J. S. (1961). The art of discovery. Harvard Educational Review, 31, 21-32.

Cakir, M. (2008). Constructivist approaches to learning in science and their implication for science pedagogy: A literature review. International Journal of Environmental and Science Education, 3(4), 193-206.

Christie, F. (2002). Classroom discourse analysis: A functional perspective. London: Continuum. 
Cross, D., \& Lepareur, C. (2015). PCK at stake in teacher-student interaction in relation to students' difficulties. In M. Grangeat (Ed.), Understanding science teachers' professional knowledge growth (s. 47-61). Rotterdam: Sense.

Činčera, J. (2013). Badatelé.cz: evaluačni zpráva. Technická Univerzita v Liberci.

Dewey, J. (1938). Logic: The theory of inquiry. New York: Holt.

Dolin, J., \& Evans, R. H. (2018). Transforming assessment: Through an interplay between practice, research and policy. Cham: Springer.

Dorier, J.-L., \& Maaß, K. (2014). Inquiry-based mathematics education. In S. Lerman (Ed.), Encyclopedia of mathematics education (s. 300-304). Dordrecht: Springer.

Evans, R. H., Ropohl, M., Nielsen, J. A., \& Papadouris, N. (2016). Affordances and challenges of written feedback as formative assessment in inquiry-based STEM education. Abstract from NARST Conference, Baltimore, USA.

Harlen, W. (2013). Assessment \& inquiry-based science education: Issues in policy and practice. Trieste: Global Network of Science Academies, Science Education Programme.

Hattie, J., \& Timperlay, H. (2007). The power of feedback. Review of Educational Research, 77(1), 81-112.

Heritage, M. (2007). Formative assessment: What do teachers need to know and do?. Phi Delta Kappan, 89(2), 140-145.

Hošpesová, A. (2016). Badatelsky orientovaná výuka matematiky na 1. stupni základního vzdělávání. Orbis Scholae, 10(2), 117-130.

Hošpesová, A. (2018). Formative assessment in inquiry-based elementary mathematics. In Kaiser, G. et al. (Eds.), Invited lectures from the 13th International Congress on Mathematical Education (s. 249-268). Cham: Springer.

Jančaříková, K., \& Novotná, J. (2019). Posing good questions - why are good questions posed not always good? In J. Fejfar et al. (Eds.), Proceedings of the 16th International Conference Efficiency and Responsibility in Education 2019 (s. 105-112). Praha: CULS.

Janík, T., Slavík, J., Mužík, V., Trna, J., Janko, T., Lokajičková, V., ... \& Zlatníček, P. (2013). Kvalita (ve) vzděláváni: obsahově zaměrený prístup ke zkoumání a zlepšováni výuky. Brno: Masarykova univerzita.

Kirschner, P. A., Sweller, J., \& Clark, R. E. (2006). Why minimal guidance during instruction does not work: An analysis of the failure of constructivist, discovery, problem-based, experiential, and inquiry-based teaching. Educational Psychologist, 41(2), 75-86.

Kolb, D. A., \& Fry, R. (1975). Toward an applied theory of experiential learning. In C. Cooper (Ed.), Studies of group process (s. 33-57). New York: Wiley.

Kosíková, V., \& Černá, K. (2013). Výzkum kvality informační funkce hodnocení ve středoškolské praxi. Pedagogika, 63(3), 372-392.

Laufková, V. (2017). Formativní hodnocení v praxi české základní školy. Pedagogika, 67(2), 126-146.

Leahy, S., Lyon, C., Thompson, M., \& Wiliam, D. (2005). Classroom assessment: Minute by minute, day by day. Assessment to Promote Learning, 63(3), 19-24. 
Magnusson, S., Krajcik, J., \& Borko, H. (1999). Nature, sources, and development of pedagogical content knowledge for science teaching. In J. Gess-Newsome \& N. G. Lederman (Eds.), Examining pedagogical content knowledge: The construct and its implications for science education (s. 95-132). Kluwer Academic Publishers.

Mathan, S. A., \& Koedinger, K. R. (2005). Fostering the intelligent novice: Learning from errors with metacognitive tutoring. Educational Psychologist, 40(4), 257-265.

Mayer, R. (2004). Should there be a three-strikes rule against pure discovery learning? The case for guided methods of instruction. American Psychologist, 59(1), 14-19.

MŠMT (Ministerstvo školství, mládeže a tělovýchovy). (2017). Rámcový vzdělávací program pro základni vzděláváni. Praha: MŠMT. Dostupné z http://www.msmt.cz/ file/43792/

NRC (National Research Council). (1996). National science education standards. Washington, DC: National Academy Press.

Nicol, D., \& Macfarlane-Dick, D. (2006). Formative assessment and self-regulated learning: A model and seven principles of good feedback practice. Studies in Higher Education, 31, 199-218.

Nocar, D., Polejová, P. \& Laitochová, J. (2017). ICT podpora badatelsky orientovaného př́istupu ve výuce matematiky na 2. stupni základních škol. South Bohemia Mathematical Letters, 25(1), 66-86.

Novák, B., \& Nováková, E. (2014). Inquiry based mathematics education (IBME) and its reflection by primary school teachers. Scientific Issues Mathematics, 19, 121-127.

Novotná, K., \& Krabsová, V. (2013). Formativní hodnocení: případová studie. Pedagogika, 63(3), 355-371.

Panadero, E., Romero, M., \& Strijbos, J. W. (2013). The impact of a rubric and friendship on peer assessment: Effects on construct validity, performance, and perceptions of fairness and comfort. Studies in Education Evaluation, 39(4), 195-203.

Papáček, M. (Ed.). (2010). Didaktika biologie v České republice 2010 a badatelsky orientované vyučování (DiBi 2010). Jihočeská univerzita v Českých Budějovicích.

Pólya, G. (2016). Jak to řešit? Praha: MatfyzPress.

Radvanová, S., Č́žzová, V., \& Martinková, P. (2018). Mění se pohled učitelů na badatelsky orientovanou výuku? Scientia in Educatione, 9(1), 81-103.

Raes, A., Vanderhoven, E., \& Schellens, T. (2015). Increasing anonymity in peer assessment by using classroom response technology within face-to-face higher education. Studies in Higher Education, 40(1), 178-193.

Rocard, M., Csermely, P., Jorde, D., Lenzen, D., Walberg-Henriksson, H., \& Hemmo, V. (2007). Science education now: A renewed pedagogy for the future of Europe. Luxembourg: Office for Official Publications of the European Communities.

Rokos, L., \& Lišková, J. (2019). Kvalita vrstevnické zpětné vazby při badatelské úloze z biologie člověka v hodinách př́rodopisu. Pedagogická orientace, 29(1), 43-72. 
Rokos, L., \& Vomáčková, V. (2017). Hodnocení efektivity badatelsky orientovaného vyučování v laboratorních pracích při výuce fyziologie člověka na základní škole a nižším stupni gymnázia. Scientia in Educatione, 8(1), 32-45.

Rokos, L., Závodská, R., Petr, J., \& Papáček, M. (2016). Formative assessment methods in biology education: Pedagogical study at primary school in the Czech Republic. Bulletin of the South Ural State University. Series Education, Educational Sciences, 8(4), 94-99.

Ruiz-Primo, M. A., \& Furtak, E. M. (2006). Informal formative assessment and scientific inquiry: Exploring teachers' practices and student learning. Educational Assessment, 11(3-4), 237-263.

Rutherford, F. J. (1964). The role of inquiry in science teaching. Journal of Research in Science Teaching, 2, 80-84.

Samková, L. (2018). Uplatnění otevřeného přístupu k matematice v př́ípravě budoucích učitelů 1 . stupně Z $\check{S}$ - empirická studie v kontextu badatelsky orientovaného kurzu. Studia Paedagogica, 23(3), 49-67.

Samková, L., Hošpesová, A., Roubíček, F., \& Tichá, M. (2015). Badatelsky orientované vyučování matematice. Scientia in Educatione, 6(1), 91-122.

Samková, L., Hošpesová, A., \& Tichá, M. (2016). Role badatelsky orientované výuky matematiky v př́ípravě budoucích učitelů 1. stupně ZŠ. Pedagogika, 66(5), 549-569.

Schoenfeld, A. H., \& Kilpatrick, J. (2013). A US perspective on the implementation of inquiry-based learning in mathematics. ZDM Mathematics Education, 45, 901-909.

Scriven, M. (1967). The methodology of evaluation. In R. W. Tyler, R. M. Gagné \& M. Scriven (Eds.), Perspectives of curriculum evaluation (s. 39-83). Chicago, IL: Rand McNally.

Shánilová, I. (2010). Hodnocení žáků základních škol. Orbis scholae, 4(1), 41-53.

Shavelson, R. J., Young, D. B., Ayala, C. C., Brandon, P. R., Furtak, E. M., Ruiz-Primo, M. A., et al. (2008). On the impact of curriculum-embedded formative assessment on learning: A collaboration between curriculum and assessment developers. Applied Measurement in Education, 21(4), 295-314.

Starý, K., \& Laufková, V. et al. (2016). Formativní hodnocení ve výuce. Praha: Portál.

Steffe, L., \& Gale, J. (1995). Constructivism in education. Hillsdale, NJ: Lawrence Erlbaum Associates.

Šed’ová, K., Švaříček, R., \& Šalamounová, Z. (2012). Komunikace ve školni třídě. Praha: Portál.

Škoda, J., Doulík, P., Bílek, M., \& Šimonová, I. (2015). The efficiency of inquiry-based science instruction in relation to the learners' motivation types. Journal of Baltic Science Education, 14(6), 791-803.

Tsivitanidou, O. E., Gray, P., Rybska, E., Louca, L., \& Constantinou, C. P. (2018). Professional development for inquiry-based science teaching and learning. Cham: Springer.

Vácha, Z., \& Ditrich, T. (2016). Efektivita badatelsky orientovaného vyučování na primárním stupni základních škol v př́rodovědném vzdělávání v České republice s využitím prostředí školních zahrad. Scientia in Educatione, 7(1), 65-79. 
Wiliam, D., \& Leahy, S. (2016). Zavádèni formativniho hodnoceni - praktické techniky pro základni a středni školy. Praha: EDUkační LABoratoř.

Žlábková, I., Petr, J., Stuchlíková, I., Rokos, L., \& Hošpesová, A. (2020). Development of teachers' perspective on formative peer assessment. International Journal of Science Education (online).

RNDr. Libuše Samková, Ph.D.

Jihočeská univerzita v Českých Budějovicích, Pedagogická fakulta, Katedra matematiky;

e-mail:lsamkova@pfjcu.cz

Mgr. Lukáš Rokos, Ph.D.

Jihočeská univerzita v Českých Budéjovicích, Pedagogická fakulta, Katedra biologie;

e-mail:lrokos@pfjcu.cz

PhDr. Jan Petr, Ph.D.

Jihočeská univerzita v Českých Budějovicích, Pedagogická fakulta, Katedra biologie;

e-mail: janpetr@pf.jcu.cz

prof. PaedDr. Iva Stuchliková, CSc.

Jihočeská univerzita v Českých Budějovicích, Pedagogická fakulta, Katedra psychologie;

e-mail: stuchl@pf.jcu.cz

\section{SAMKOVÁ, L., ROKOS, L., PETR, J., STUCHLÍKOVÁ, I. A Theoretical Model for Formative Assessment during Inquiry-based Mathematics and Science Education}

The theoretical study presented here focuses on issues related to the interconnection offormative assessment and inquiry-based education in school practice and approaches the issues jointly for mathematics and science subjects (specifically natural history). On the basis of common features of inquiry-based education in both subjects, and using a communication model for describing on-the-fly assessment interactions, we created a new general model designed to describe formative assessment interactions during inquiry-based education. The resulting theoretical model is introduced through a collection of diagrams that generally describe the course of lessons with inquiry tasks from the perspective of formative assessment, and through a newly-established communication model (called the double ESRU model) that aims to code various types of formative assessment interactions. The possibilities offered by the theoretical model are illustrated 
by detailed analysis of two virtual lessons with an inquiry task; the first lesson is in mathematics, the second in natural history. From the perspective of educational research, the model that is presented offers a tool for detailed apposite analysis of formative assessment during inquirybased education. From the perspective of teachers and future teachers, the model offers a tool for supporting the implementation of formative assessment and inquiry-based education into their own teaching practice. The visualisation of the interconnection of the two approaches and the independence of the model from the school subject should help to provide an understanding of the possibilities that formative assessment offers for inquiry-based education.

Keywords: inquiry-based education, formative assessment, interactions, mathematics education, science education 